\title{
The Book of Chronicles through the Ages: A Cinderella or a Sleeping Beauty?
}

\section{Introduction}

\begin{abstract}
That Cinderella of the Hebrew Bible, Chronicles, has at last emerged from years of obscurity and scorn. Early last century she was all the rage among scholars who used her quite shamelessly in their battles over the reconstruction of Israelite history. But then, when the conflict was over, Wellhausen turned on her in favour of her Deuteronomistic stepsister and sent her packing for her unfashionable love of ritual and family ties, and for allegedly playing fast and loose with the facts. How things have changed over the last decade! She may not yet be the belle of the academic ball, but she has, at least, been noticed in her own right once again and has received long overdue attention from the scholarly community. ${ }^{1}$
\end{abstract}

This quotation from John W. Kleinig (North Adelaide, Australia) captures in expressive images the changes of attitude towards Chronicles that occurred in the past fifty years. For a long time, the Book of Chronicles was never at the center

1 John W. Kleinig, “Recent Research in Chronicles,” Currents in Research. Biblical Studies 2 (1994): 43-76, here 43. Among recent works used for this short survey, we must mention, besides Kleinig's article and, among others, some important studies and monographs by Dietmar Mathias, Die Geschichte der Chronikforschung im 19. Jahrhundert unter besonderer Berücksichtigung der exegetischen Behandlung der Prophetennachrichten des chronistischen Geschichtswerkes. Ein problemgeschichtlicher und methodenkritischer Versuch auf der Basis ausgewählter Texte (Dissertation zur Promotion A; Leipzig: Karl-Marx-Universität, 1977); Sara Japhet, "The Historical Reliability of Chronicles: The History of the Problem and its Place in Biblical Research,” JSOT 33 (1985): 83-107; Hugh G.M. Williamson, "Introduction," in Martin Noth, The Chronicler's History. Translated by Hugh G.M. Williamson with an introduction, JSOT.S 50 (Sheffield: JSOTPress, 1987), 11-26; Kai Peltonen, History Debated: The Historical Reliability of Chronicles in Pre-Critical and Critical Research 2. Vols. Publications of the Finnish Exegetical Society 64 (Helsinki: The Finnish Exegetical Society, 1996); Thomas Willi, "Zwei Jahrzehnte Forschung an Chronik und Esra-Nehemia,” Theologische Rundschau NF 67 (2002): 61-110; Rodney K. Duke, "Recent Research in Chronicles," Currents in Biblical Research 8 (2009): 10-50; Isaac Kalimi, The Retelling of Chronicles in Jewish Tradition and Literature: A Historical Journey (Winona Lake, IN: Eisenbrauns, 2009); Louis C. Jonker, "Within Hearing Distance? Recent Developments in Pentateuch and Chronicles Research,” Old Testament Essays 27 (2014): 123-46; Louis C. Jonker, "From Paraleipomenon to Early Reader: The Implications of Recent Chronicles Studies for Pentateuchal Criticism," in Congress Volume Munich 2013, VTSup 163, ed. Christl M. Maier (Leiden: Brill, 2014), 217-54.

Jean-Louis Ska, Pontifical Biblical Institute 
of attention in biblical research. From the beginnings of exegesis, as early as the Greek translation of the Septuagint ( $2^{\text {nd }}$ century BCE), Chronicles is something like

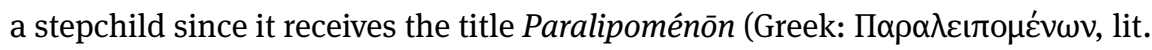
'things left on one side,' or something like 'left overs'). This title suggests that the Greek translators found in these books mainly materials not present elsewhere, namely in the Pentateuch and especially in Samuel-Kings.

The usual title “Chronicles" goes back to Jerome's translation into Latin in the $5^{\text {th }}$ century. The title evokes the presence of archives, records, accounts classified or organized in a chronological order - from the Greek word xpóvoৎ, "time."2 The temporal dimension of the Books was essential for Jerome. Chronicles begins with Adam's genealogy, and concludes with Cyrus the Great's edict (ca. 539 BCE). In a certain sense, we are invited to see in Chronicles a compilation of records about a history beginning with Adam's creation and ending with Cyrus the Great's edict. This is obviously just one way of characterizing the book that closes the third part of the Hebrew canon in several manuscripts, but not in all of them. ${ }^{3}$

The Book of Chronicles is rarely treated in a positive way, and this is the case already in rabbinical and patristic exegesis. There are several reasons for this state of affairs. One aspect of the question may explain, to a certain extent, why this book was often considered as a kind of second-class member of the canon. Chronicles, in fact, repeats several parts, or seems to re-use many elements present in other biblical books, partly in the Pentateuch and more fully in Samuel-Kings. These books were already considered as inspired and authoritative, especially the Pentateuch. Now, there are noticeable differences between Chronicles and these other writings. The tendency was, spontaneously, to give preference to the most respected books of the Tanakh at the expense of Chronicles that was relegated among the Ketûbîm. The history of exegesis will confirm this view and, in certain cases, add some nuances.

My purpose, in this short essay, is not to supply the reader with a complete and exhaustive history of research about Chronicles. This is impossible. On the other hand, several studies or monographs mentioned in the footnotes will provide the interested reader with all the pieces of information needed. Moreover, the numerous recent commentaries on Chronicles contain excellent introductions and status

2 For more details on this point, see, among others, Gary N. Knoppers, 1 Chronicles 1-9, AB 12.1 (New York: Doubleday, 2003), 47.

3 See, for instance, Edmon L. Gallagher, "The End of the Bible? The Position of Chronicles in the Canon,” Tyndale Bulletin 65 (2014): 181-99; see also Gary N. Knoppers, "Chronicles and Canon," in Knoppers, I Chronicles 1-9, 135-7; Greg Goswell, "The Order of the Books in the Hebrew Bible," JETS 51/4 (2008): 673-88. In the Aleppo Codex and in the Saint-Petersburg Codex, the last book is Ezra-Nehemiah. 
quaestionis (inter alia Japhet, Johnstone, Knoppers, Klein, Levin, Willi, Dirksen, Tuell, Williamson). It is not necessary to repeat here what others have exposed with much competence. My purpose is rather to explain what the major steps in the exegesis of Chronicles are and to inquire about the main cultural and intellectual factors that influenced it. Biblical studies do not develop within a vacuum, they breathe the air of their time and hum the popular melodies of their age.

\section{Early rabbinic exegesis}

According to the Talmud, Chronicles forms only one book and its redaction is attributed to Ezra, an attribution that would last for long (Baba Bathra 15a). ${ }^{4}$ As for its intrinsic value, Rabbinical and Talmudic authorities already distrusted Chronicles' historical accuracy. The reasons are twofold. First, they were of the opinion that this book was meant for homiletic interpretation rather than for other, more precise, purposes (Lev. R. i.3; Ruth R. ii., beginning; cf. Meg. 13a). Second, the personal names were treated with great freedom, for instance in the genealogies. In some cases, names which had clearly been ascribed to different persons were declared, in other places, to designate one and the same man or woman (Soțah 12a; Ex. R. i. 17, et passim). ${ }^{5}$

We perceive here the first signs of a critical attitude towards Chronicles. Rabbis compared Chronicles with the other books of the Tanakh or elements present in different parts of Chronicles, detected tensions and contradictions, and concluded that Chronicles was inaccurate. ${ }^{6}$

This may also explain the reason why Chronicles was rarely commented in Antiquity. We have to wait until the time of Saadia Gaon (882-942), Rashi (1040-1105) and David Kimhi (1160-1235) to have the first rabbinic commentaries on Chronicles. ${ }^{7}$ To be sure, the commentary ascribed to Rashi was written by someone else, most probably in Germany, and therefore called Pseudo-Rashi's

\footnotetext{
4 For more details on the place of Chronicles in Jewish tradition, see, for instance, Isaac Kalimi, The Retelling of Chronicles in Jewish Tradition and Literature: A Historical Journey (Winona Lake, IN: Eisenbrauns, 2009), 141-54.

5 Jewish Encyclopedia http://www.jewishencyclopedia.com/articles/4371-chronicles-books-of consulted 07/09/2019.

6 Kalimi, The Retelling of Chronicles, 145-8.

7 See Eran Viezel, "The Anonymous Commentary on the Books of Chronicles Attributed to a Student of Sa'adia Gaon: Its Status in the History of the Jewish Peshat Exegesis,” Tarbiz 76 (2007): 415-34; Kalimi, The Retelling of Chronicles, 193-7.
} 
commentary. ${ }^{8}$ Another commentary, but preserved only in fragments, was written by Joseph Kara (c. 1065-c. 1135), Rashi's companion and colleague. Pseudo-Rashi alludes to this work. ${ }^{9}$ David Kimhi (Radak), following the Talmud's opinion, considered that Chronicles was written by Ezra who used earlier sources in composing his work. ${ }^{10}$ Radak's opinion is of a certain value because he takes the lead of those exegetes who saw in Chronicles mainly a historian. This view was contradicted some time later by Isaac Abravanel (1437-1508) who insisted more on the theological flavour of the book. ${ }^{11}$ As we will see, views on Chronicles would oscillate frequently between these two positions, history or theology. ${ }^{12}$

\section{Negative opinions}

Joseph Solomon del Medigo o Delmedigo (Candia, Crete, 16 June 1591 - Praga, 16 October 1655), a Jewish scholar, physician, astronomist and mathematician, expresses an opinion about Chronicles which is representative of what most intellectuals thought in that time. ${ }^{13}$ For him, the writer of Chronicles is fundamentally

8 See Eran Viezel, The Commentary on Chronicles Attributed to Rashi (Jerusalem: Magnes Press, 2010) [Hebrew]. For the original text, see the site https://www.sefaria.org/Rashi_on_I_ Chronicles?lang=bi - consulted 29/08/2019; Avraham Grossman, "Solomon Yishaqi/Rashi (1040-1105)," in Hebrew Bible/Old Testament: The History of Its Interpretation. I/2: The Middle Ages [hereafter HBOT I.2], ed. Magne Sæbø (Göttingen: Vandenhoek \& Ruprecht, 2000), 332-46, here 333. Cf. Kalimi, The Retelling of Chronicles, 199-209.

9 On this author, see https://www.jewishvirtuallibrary.org/kara-joseph - consulted 29/08/2019. See also Avraham Grossman, "Joseph Kara," in HBOT I.2, 346-56. Cf. Kalimi, The Retelling of Chronicles, 238.

10 On David Kimhi/Radak, see Mordecai Cohen, “The Qimhi Family,” in HBOT I.2, 388-415 espec. "David Qimhi (Radak),” 396-415. For his commentary on Chronicles, see Yitzhak Berger, The Commentary of Rabbi David Kimhi to Chronicles: A Translation with Introduction and Supercommentary (Providence, RI: Brown University, 2007). Cf. Kalimi, The Retelling of Chronicles, 220-9.

11 The texts can be found in the Biblia rabbinica or Mikraot Gdolot (Venice: Daniele Bomberg, 1516-1517; reprinted in 1568); Biblia Rabbinica con Targums, Revised by Leon of Modena with a foreword (Venice: Pietro e Lorenzo Bragadin, 1617-1619).

12 See Thomas Willi, Chronik: 1. Teilband 1. Chronik 1,1 - 10,14, BK XXIV/1 (Neukirchen-Vluyn: Neukirchner, 2009), vii. On Isaac Abravanel, see Eric Lawee, "Isaac Abarbanel: From Medieval to Renaissance Jewish Biblical Scholarship," in Hebrew Bible/Old Testament: The History of Its Interpretation. II: From Renaissance to Enlightenment [hereafter HBOT II], ed. Magne Sæbø (Göttingen: Vandenhoeck \& Ruprecht, 2008), 190-214.

13 On del Medigo, see Isaac Barzilay, Yoseph Shlomo Delmedigo (Yashar of Candia): His Life, Works and Times, Studia Post-biblica 25 (Leiden: Brill, 1974); Jacob Adler, "Joseph Solomon 
unreliable for one main motive, namely that he lived a long time after the destruction of the First Temple. This is the reason why he was included into the Ketûbîm or Hagiographa. Moreover, there is much disagreement between the different versions of the same event in these late compositions. We may notice a critical spirit in these remarks, a rational or rationalist spirit stemming from Greek historians and philosophers. ${ }^{14}$ Here is his opinion in a few sentences ${ }^{15}$ :

[The writer of Chronicles] lived a long time after the first destruction [...] and therefore it was included among the Hagiographa [...] and you should know these post-destruction stories, how they vary, like most of the modern historiographies, where you will find no two in agreement on one single event.

\section{We find a similar reaction in Baruch Spinoza (1632-1677) ${ }^{16}$ :}

But about the two books of Chronicles I have nothing certain and worthwhile to say except that - contrary to a tradition that makes Ezra their author - they were written long after Ezra, and perhaps after Judas Maccabee restored the temple. [...] Nothing is apparent to me about the true writer of these books, or about their authority, their utility or their doctrine. In fact, I am amazed at their being accepted as sacred by the people who removed the Book of Wisdom, Tobias, and the rest of the so-called apocrypha from the canon of sacred books. But I am not trying to lessen their authority; everyone accepts them, so I leave it at that. ${ }^{17}$

Delmedigo: Student of Galileo, Teacher of Spinoza," Intellectual History Review 23.1 (2013): 141-57. Delmedigo was a great traveler. We count Venice, Alexandria and Cairo (Egypt), Istanbul, Wilna, Hamburg, Amsterdam, Frankfort-on-the-Main, and Praga among the cities he visited.

14 See Japhet, "Historical Reliability," 83-4. Source: Yoseph Shelomo del Medigo, Matzref Lahochma, ed. Sh. Ashkenazi (Basel: Ashkenazi, 1629), 29b. On the man and his works, see Issac Barzilai, Yoseph Shlomo Delmedigo (Yashar of Candía), Studia Post-Biblica 25 (Leiden: Brill, 1974), esp. 299-304; David Geffen, "Insights into the Life and Thought of Elijah Medigo Based on His Published and Unpublished Works," Proceedings of the American Academy for Jewish Research 41/42 (1973-1974): 69-86. Cf. Kalimi, The Retelling of Chronicles, 294-6.

15 Japhet, "Historical Reliability," 83.

16 On Spinoza, see Rudolf Smend, "Baruch de Spinoza (1632-1677),” in Rudolf Smend, Kritiker und Exegeten. Porträtskizzen zur vier Jahrhunderten alttestamentlicher Wissenschaft (Göttingen: Vandenhoeck \& Ruprecht, 2017), 50-66. See also Steven Nadler (ed.), Spinoza and Medieval Jewish Philosophy (Cambridge: Cambridge University Press, 2014); Jeffrey L. Morrow, Three Skeptics and the Bible: La Peyrère, Hobbes, Spinoza, and the Reception of Modern Biblical Criticism (Eugene, OR: Pickwick, 2016). Cf. Kalimi, The Retelling of Chronicles, 296-302.

17 Baruch Spinoza, Tractatus theologico-politicus (Hamburg: Kühnrat, 1670), ch. 10. Quotation from Baruch Spinoza from J. Israel and M. Silverthorne, Theological-Political Treatise, Cambridge Texts in the History of Philosophy (Cambridge: Cambridge University Press, 2007), with some slight modifications to clarify Spinoza's thought. For a translation on the web, see https://www. earlymoderntexts.com/assets/pdfs/spinoza1669.pdf - consulted on 29/08/2019. 
Two points are of importance. First, Ezra is no longer considered the author of Chronicles; second, the date of composition is pushed as late as the time of the Maccabees, in the $2^{\text {nd }}$ century BCE. Of course, this statement undermines even more the historical value of the book since there is a longer temporal distance between Chronicles and the events recounted therein. Spinoza, as we know, was condemned by the authorities of the Synagogue, by the Church and even by the civil authorities of his city, Amsterdam. His ambivalent statement explains partly why he had little effect on the exegesis of Chronicles in his time. Anyway, Chronicles was surely not at the center of attention either.

Spinoza's doubts about the inspiration of Chronicles, however, were taken seriously by some other scholars, among them Georg Ludwig Oeder (1694-1760) who tried to prove that Chronicles was not divinely inspired and, therefore, had no place in the canon of Scriptures. ${ }^{18}$ After being located to the bottom floor of Scriptures, Chronicles was about to be expelled to the street.

\section{Wilhelm Martin Leberecht de Wette (1780-1849)}

A major turn in the exegesis of Chronicles occurred with Wilhelm Martin Leberecht de Wette who undoubtedly determined the study of the book for a long time. ${ }^{19}$

De Wette published his Beiträge zur Einleitung in das Alte Testament - Contributions to the Introduction into the Old Testament in $1807 .{ }^{20}$ There were two volumes, and the subtitles reveal the exact purpose of the work. The first volume is entitled Kritischer Versuch über die Glaubwürdigkeit der Bücher der Chronik mit Hinsicht auf die Geschichte der Mosaischen Bücher und Gesetzgebung. Ein Nachtrag zu den Vaterschen Untersuchungen über den Pentateuch - Critical Essay on the Reliability of the Books of Chronicles with Respect to the History of the Mosaic Books and Legislation: A Supplement to Vater's Investigation on the Pentateuch and the second, Kritik der Mosaischen Geschichte - Critique of the Mosaic History.

18 Georg Ludwig Oeder, Freye Untersuchungen über einige Bücher des Alten Testament (Hrsg. Georg Johann Ludwig Vogel) (Halle: Hendel, 1771), 137-246; Rudolf Smend, Wilhelm Martin Leberecht de Wettes Arbeit am Alten und am Neuen Testament (Basel: Helbing \& Lichtenhahn, 1958), 41. Georg Ludwig Oeder was active in Heilbronn, Ansbach and Feuchtwangen.

19 On De Wette, see Rudolf Smend's work cited in the previous note; John W. Rogerson, W.M.L. de Wette, Founder of Modern Biblical Criticism: An Intellectual Biography (Sheffield: Academic Press, 1992).

20 Wilhelm Martin Leberecht de Wette, Beiträge zur Einleitung in das Alte Testament (Halle: Schimmelpfennig, 1807; Hildesheim: Georg Holms, 1971). 
The important word in the first subtitle is Glaubwürdigkeit - Reliability. We are dealing with a historical inquiry and de Wette's endeavours to find out whether we can rely on the Books of Chronicles, especially in what it says about the law of Moses. There were many discussions at that time about the Mosaic authorship of the Pentateuch, a problem connected with the authority and inspiration of the Torah. This problem was hotly debated, as everyone knows. But why does de Wette starts his inquiry with the Books of Chronicles? The reason is that the Old Testament offers two parallel histories of ancient Israel, Samuel-Kings on the one side and Chronicles on the other side. One of the main differences between the two presentations is that Chronicles, contrary to Samuel-Kings, contains many references to Moses' law. This law is constantly presented as the blueprint for the building of the temple and the organization of the cult. It is as if David and Solomon were constantly consulting the law of Moses before taking any decision in cultic matters. Every item in the building of the temple and every element in the cult conform to the prescriptions found in Moses' law. ${ }^{21}$ The allusions are moreover to 'what is written in Moses' Law.' ${ }^{22}$

This fact was used by many scholars to show the antiquity of Moses' law since, according to Chronicles, it must have been known at the time of David and Solomon. On the other hand, it seems that Samuel-Kings ignore almost completely Moses' Law, apart from a very few exceptions (cf. 2Kgs 14:6). De Wette, for his part, opts for Samuel-Kings and undermines Chronicles radically, insisting on its ideological and theological biases. Chronicles was also written much later than the events described and is, for this reason, untrustworthy. Altogether, Chronicles is a negligent, inaccurate, work that reveals patent tendentiousness, expressed for instance in the author's preference for the Levites, his predilection for the temple and the cult, his fondness for Judah and his hostility towards Israel.

We may ask, however, why de Wette wanted to demonstrate that the Pentateuch was written much later than Moses and was not a source of historical

21 Moses is mentioned in 1 Chr 6:34, 15:15, 21:29, 22:13, 23:15, 26:24, 2 Chr 1:3, 5:10, 8:13, 23:18, 24:6, 9, 25:4, 30:16, 33:8, 34:14, 35:6, 12 (18x). The legislation of Moses is mentioned explicitly in 2 Chr 8:13, 23:18, 25:4, 30:16, 33:8, 34:14, 35:6, 12.

$222 \mathrm{Chr} 23: 18$; 25:4; 30:5, 18; 31:3; 35:12, 26. For more details on this point, see Arthur Charles Hervey, The Book of Chronicles in Relation to the Pentateuch and "Higher Criticism" (London: Society for Promoting Christian Knowledge - New York: Brighton, 1892); Thomas Willi, “'Wie geschrieben steht' - Schriftbezug und Schrift. Überlegungen zur frühjüdischen Literaturwerdung im perserzeitlichen Kontext," in Thomas Willi, Israel und die Völker. Studien zur Literatur und Geschichte Israels in der Perserzeit, SBAB 55 (Stuttgart: Verlag Katholisches Bibelwerk, 2012), 101-22; Knoppers, I Chronicles 1-9, 123-6 (“As It Is Written: The Chronicler’s Source Citations”). 
information. Three elements in de Wette's formation are essential for the understanding of his exegesis.

(1) First, de Wette was influenced much by Immanuel Kant's philosophy that he read during his studies in Jena. ${ }^{23}$ This was a major element in his education although he also met with other great writers and philosophers in Weimar, for instance Wolfgang Goethe, Friedrich Schiller and especially Johann Gottfried von Herder $^{24}$, or in Jena where he was in touch with Johann Gottlieb Fichte, Georg Wilhelm Friedrich Hegel, Friedrich Schelling and Jakob Friedrich Fries, the latter being a disciple of Kant. After reading de Wette, one cannot avoid noticing the parenthood between his ideas and Kant's theory of a Die Religion innerhalb der Grenzen der bloßen Vernunft - Religion within the Boundaries of Mere Reason (1793). This title expresses very well what was the intellectual atmosphere in that time and also explains why there was a strong suspicion towards every supranatural phenomenon, either miracle or oracle, in academic circles. The tendency was to look, first of all, for rational or natural explanations for such phenomena.

Other scholars may have had some influence on de Wette's formation, as for instance, still in Jena, Johann Jakob Griesbach (1745-1812), a disciple of Semmler, Heinrich Eberhard Gottlob Paulus (1761-1851), Johann Philipp Gabler (1753-1826) and Karl David Ilgen (1763-1834), a very critical spirit, who probably encouraged de Wette to meet with Johann Severin Vater (1771-1826). Vater's work duplicated that of de Wette to a certain extent since de Wette was, for a while, a "fragmentist" just as Vater. ${ }^{25}$

Paulus, to come back to this New Testament scholar, was another disciple of Kant, and he applied theological rationalism to the Scriptures, eliminating for instance any supranatural reference from the gospels. Gabler, for his part, is often considered as the founder of biblical theology as a discipline independent from dogmatic theology, in his writing De justo discrimine theologiae biblicae et dog-

23 For these pieces of information, see Rudolf Smend, "Wilhelm Martin Leberecht de Wette (1780-1849)," in Kritiker und Exegeten, 192-206. See also Rogerson, W.M.L. de Wette, 19-63. On Kant's influence on biblical interpretation, see, among others, Jan Rohls, "Historical, Cultural and Philosophical Aspects of the Nineteenth Century with Special Regard to Biblical Interpretation," Hebrew Bible/Old Testament: The History of Its Interpretation. III/1: The Nineteenth Century - A Century of Modernism and Historicism [hereafter HBOT III.1], ed. Magne Sæbø (Göttingen: Vandenhoeck \& Ruprecht, 2013), 31-63, esp. 34-5.

24 On Herder, see, for instance, Thomas Willi, Herders Beitrag zum Verstehen des Alten Testaments, Beiträge zur Geschichte der biblischen Hermeneutik 8 (Tübingen: Mohr Siebeck, 1971); Henning Graf Reventlow, "Johann Gottfried Herder - Theologian, Promotor of Humanity, Historian," in HBOT II, 1041-50; Smend, Kritiker und Exegeten, 154-75.

25 De Wette mentions explicitly Ilgen and Vater among his predecessors and inspirers (Beiträge, iv). 
maticae regundisque recte utriusque finibus - On the Correct Distinction between Dogmatic and Biblical Theology and the Right Definition of Their Goals (1787). All these scholars helped de Wette sharpen his critical sensitivity in reading biblical texts especially in historical matters.

(2) The second important element in de Wette's formation is the idea of "myth" which becomes central especially in his understanding of the Pentateuch. ${ }^{26}$ The word "myth" in de Wette's work has a precise meaning. "Myth" is a scenic, picturesque expression of a worldview and of a self-understanding in a given culture. This type of thinking is characteristic of ancient cultures, for instance in Greece and in the Ancient Near East. The idea itself does not come from de Wette, but from Christian Gottlob Heyne (1729-1812), a specialist of Homer. Once again, we must admit that many leading ideas in biblical exegesis stem from classical studies, especially Homeric studies. ${ }^{27}$ This was already the case in antiquity. We may remember that Karl David Ilgen was also a specialist of Homer and taught classical literature in Jena.

The concept of myth, developed by Christian Gottlob Heyne (1729-1812), was first adopted by Johann Gottfried Eichhorn (1752-1827) who taught in Jena and Göttingen. ${ }^{28}$ De Wette knew Eichhorn and was often in dialogue with him. More concretely, de Wette disagreed with Eichhorn on the way of interpreting the presence of "myths" in biblical literature. Eichhorn tried to trace a middle path between supernaturalism and orthodoxy, on the one hand, and rationalism and enlightenment on the other. More concretely, he tried to find some historical kernels in biblical narratives, especially in the Pentateuch. For de Wette, on the contrary - and in a way like Ilgen and Paulus - it was impossible to find history behind ancient myths. Under the mythical language, or under the mythical varnish, we discover religion, not history. There are therefore two sides in de Wette's exegesis. The first is negative, and its purpose is to demonstrate the absence of history - in the modern sense of the word - in the Pentateuch. The

26 "Was man vielleicht für zu kühn erkennen wird, daß ich den ganzen Pentateuch von Anfang bis zu Ende in mythischer Bedeutung nehme, ist doch weiter nichts als Konsequenz: denn wie das Einzelne, so auch das Ganze" (Beiträge, iv) - italics mine.

27 See, for instance, Margalit Finkelberg and Guy G. Stroumsa (eds.), Homer, the Bible, and beyond: Literary and Religious Canons in the Ancient World, Jerusalem Studies in Religion and Culture 2 (Leiden - Boston: Brill, 2003); Maren R. Niehoff (ed.), Homer and the Bible in the Eyes of Ancient Interpreters, Jerusalem Studies in Religion and Culture 16 (Leiden: Brill, 2012). For earlier essays in the field, see Cyrus Gordon, "Homer and the Bible," HUCA 26 (1955): 43-108; Umberto Cassuto, The Documentary Hypothesis and the Composition of the Pentateuch (Jerusalem: Magnes Press - Hebrew University, 1961) (Hebrew: 1941), 10-1.

28 Cf. Smend, Kritiker und Exegeten, 186-7. On Eichhorn, see Smend, Kritiker und Exegeten, 176-91. 
more positive side is the exposition of the religious ideas and ideals in the texts. This second part is perhaps not sufficiently developed in de Wette's work, but this aspect was essential to him.

To come back to classical studies and its influence on biblical exegesis, de Wette considers the author of Genesis 24 as a "Canaanite Homer," he compares Jacob's journey to that of Ulysses, and finds similarities between classical epics, for instance Virgil's Aeneid, and the Elohist (the future Priestly Writer). ${ }^{29}$ All this means that we can hardly treat the Pentateuch as a historical document or as a source of historical, accurate, information.

(3) This leads us to the third aspect of de Wette's research. Along the same line as Herder, after discussions with Friedrich Lücke (1791-1855) and especially Friedrich Daniel Ernst Schleiermacher (1768 - 1834) in Berlin, de Wette looked for some new ways to solve the conflict between orthodoxy and rationalism. ${ }^{30}$ In his choice, he was guided by Immanuel Kant's third important work, Die Kritik der Urtheilskraft - The Critique of the Judgement (1790) and found there the lineaments of a conception of religion based on sensitivity (Gefühl) and aesthetics. This idea was also fostered by Jakob Friedrich Fries, Kant's disciple and de Wette's colleague. To give only one example of this way of thinking, de Wette affirms that there is no history in Genesis 22, but we should not forget the "beautiful meaning" of this poetic narrative: "Diese Mythe ist eine der schönsten in der Genesis" "This myth is one of the most beautiful in Genesis." And Abraham is "das Vorbild hebräischer Frömmigkeit" - "the model of Hebrew piety." 31 All in all, for de Wette, the roots of authentic religion are not to be looked for in historical facts or in rational arguments. Its roots are elsewhere, especially in the aesthetic and artistic aspect of biblical narratives.

All this may help us understand the reason better why de Wette insisted forcefully on the fact that Chronicles is no reliable source for Israel's ancient history. We have "myth" in the Pentateuch, we do not have history. The Pentateuch is the expression of Israel's religion, of Israel's convictions, worldview and self-consciousness. For this reason, it was essential for de Wette to demonstrate the unreliability of Chronicles, since these books affirmed, time and again, that the law of Moses, the written law, was known as early as the reign of David and Solomon. De Wette endeavored to free Israel's religion from too close an association with history and also, from some other forms of religion, such as legalism and ritualism, as in Kant and in liberal Protestantism.

29 De Wette, Beiträge, 116, 123, 32.

30 On Schleiermacher, see Jan Rohls, "F.E.D. Schleiermacher - His Criticism of the Old Testament," in HBOT III.1, 38-44.

31 De Wette, Beiträge, 103. 


\section{The Aftermath of de Wette's Proposition: Enthusiasm and Antagonism}

Handbooks usually mention de Wette's work as a turning-point in the exegesis of Chronicles but ignore or pass over in silence all the negative reactions this position provoked. Falsa est de Wettii de Pentateucho sententia is, to take just one example, the first sentence of a thesis defended in Bonn in 1823 by Ernst Wilhelm Hengstenberg (20 October 1802 - 28 May 1869). ${ }^{32}$ Other authors attacked de Wette directly and tried by all means to save the validity of Chronicles as source for a history of Israel. ${ }^{33}$ Among these authors, we may notice the names of Johann Gottfried Eichhorn and of Carl Friedrich Keil, Franz Delitzsch's disciple and colleague. The main problem, at that time, was the historicity of Chronicles, fiercely defended by all these authors who affirm that the book used reliable sources. ${ }^{34}$

Things change, eventually, with Karl Heinrich Graf ${ }^{35}$ and Julius Wellhausen. ${ }^{36}$ Both picked up de Wette's thesis and built their theories on it. For Wellhausen,

32 On Hengstenberg, see Matthias A. Deuschle, Ernst Wilhelm Hengstenberg. Ein Beitrag zur Erforschung des kirchlichen Konservatismus im Preußen des 19. Jahrhunderts, BHTh (Tübingen: Mohr Siebeck, 2013); Smend, Kritiker und Exegeten, 240-57.

33 Johann Gottfried Eichhorn, Einleitung in das Alte Testament (Leipzig: Weidmann, 1780-1783, 41823), iii, 495-8; Johannes Georg Dahler, De Librorum Paralipomenon Auctoritate atque Fide Histórica Disputatio (Strassburg und Leipzig: Gleditsch, 1819); J.M. Hertz, Sind in den Büchern der Könige Spuren des Pentateuch und der Mosaischen Gesetze zu finden? Ein Versuch zur Vertheidigung der Bücher der Chronik wie auch des Alterthums der Mosaischen Gesetze (Altona: Hammerich, 1822); Carl Peter Wilhelm Gramberg, Die Chronik nach ihren geschichtlichen Charakter und ihrer Glaubwürdigkeit neu geprüft (Halle: Eduard Anton, 1823; Florence: Nabu Press, 2012); Carl Friedrich Keil, Apologetischer Versuch über die Bücher der Chronik und über die Integrität des Buches Ezra (Berlin: Oehmigke, 1833; Warsaw: Andesite Press, 2017).

34 See, on this point, besides the article by Sarah Japhet (note 1), M. Patrick Graham, The Utilization of 1 and 2 Chronicles in the Reconstruction of Israelite History in the Nineteenth Century, SBLDS 116 (Atlanta, GA: Scholars Press, 1990); M. Patrick Graham, Kenneth G. Hoglund, and Steven L. McKenzie (eds.), The Chronicler as Historian, JSOT.S 238 (Sheffield: Academic Press, 1997); Thomas Willi, Israel und die Völker. Studien zur Literatur und Geschichte Israels in der Perserzeit. Herausgegeben von Michael Pietsch, Stuttgarter biblische Aufsatzbände 55 (Stuttgart: Katholisches Bibelwerk, 2012).

35 Karl Heinrich Graf, "Das Buch der Chronik als Geschichtsquelle,” in Karl Heinrich Graf, Die Geschichtlichen Bücher des Alten Testaments. Zwei historisch-kritische Untersuchungen (Leipzig: T.O. Weigel, 1866), 114-247. ["Die Bestandteile der historischen Bücher von Genes. 1 bis 2 Reg. 25” ("Pentateuch und Prophetae priores")].

36 Julius Wellhausen, Prolegomena zur Geschichte Israels (Berlin: Georg Reimer, 1878, ${ }^{21883 ;}$ 51899; de Gruyter Studienbuch; Berlin - New York: de Gruyter, 2001); English translation: Prolegomena to the History of Israel. Translated by S. Black and A. Menzies (Edinburgh: A. \& C. Black, 1885), 171-227. Here again, there was strong opposition to Wellhausen's views. See, for 
it was crystal-clear that Chronicles cannot be used as reliable source for a reconstruction of Israel's past. His main reasons are the following: (1) In Chronicles, Israel's past is seen through a Judaic lense, i. e. Chronicles projects into the past a picture of the Judaean post-exilic community; (2) The differences between Chronicles and 1-2 Samuel/1-2 Kings are best explained by the influence of the Priestly Code and its interest in cultic and legal matters; (3) It is not possible to prove that Chronicles had made use of valid, ancient, and trustworthy sources. All in all, Chronicles remained the Cinderella or the stepchild of biblical exegesis, especially because of its historical biases in favor of Judah and Jerusalem, and its predilection for the cult of the temple and all its paraphernalia. For Wellhausen, Chronicles was a midrash that grows like a green ivy around a dead trunk, the ivy being Chronicles and the dead trunk the old traditions. ${ }^{37}$ The word "midrash" would have some success subsequently.

Wellhausen had several followers and his influence lasted for a long a time. One question, however, received a different treatment and deserve some attention, namely the question of authorship. From the time of the Talmud (Baba Bathra 15a), Ezra was supposed to have written Chronicles or, in other words, the author of Ezra-Nehemiah composed Chronicles as well. This changed with the Jewish scholar Leopold Zunz (1794-1886). Together with other young men, among them the poet Heinrich Heine, alongside Joel Abraham List, Isaac Marcus Jost, and Eduard Gans, Zunz founded the Verein für Kultur und Wissenschaft der Juden ("The Society for the Culture and Science of the Jews") in Berlin in 1819. He was also the editor of the Zeitschrift für die Wissenschaft des Judenthums. For Zunz, Ezra was not the author of Chronicles. On the contrary, the Chronicler was the author of Ezra-Nehemiah. ${ }^{38}$ His main reason is that these books - and Zunz

instance, Wilhelm Möller, Historisch-kritische Bedenken gegen die Graf-Wellhausensche Hypothese. Von einem früheren Anhänger den Studierenden der Theologie gewidmet. Mit einem Begleitwort versehen von C. von Dressi (Gütersloh: Bertelsmann, 1899); English translation: Are the Critics Right? Historical \& Critical Considerations against the Graf-Wellhausen Hypothesis. With an introduction by C. von Orelli; translated from the German by C.H. Irwin (London: The Religious Tract Society, 1903).

On Graf, see Joachim Conrad, Karl Heinrich Grafs Arbeit am Alten Testament: Studien zu einer wissenschaftlichen Biographie (BZAW 425; Berlin: de Gruyter, 2011).

On Wellhausen, see, among many others, Rudolf Smend, Julius Wellhausen: Ein Bahnbrecher in drei Disziplinen (München: Carl von Friedrich Siemens Stiftung, 2006).

37 Wellhausen, Prolegomena, 223: “Wie Efeu umgrünt derselbe [der Midrasch der Chronik] den abgestorbenen Stamm mit fremdartigen Leben, Altes und Neues in sonderbarer Vereinigung mischend."

38 Leopold Zunz, Die gottesdienstlichen Vorträge der Juden, historisch entwickelt. Ein Beitrag zur Alterthumskunde und biblischen Kritik, zur Literatur- und Religionsgeschichte (Berlin: A. Asher, 1832; Hildesheim: Georg Olms, 1966). See Japhet, “Historical Reliability,” 88-9. 
still considered them as one literary composition - describe a historical situation from a distant viewpoint and are therefore written a long time after the events. Therefore, they cannot have been written by Ezra who is contemporary with the events. Hereby, we return, in a certain way, to Spinoza's conclusion. ${ }^{39}$

Along the same line, and independently from Zunz, Franz Karl Movers (18061856), a German Roman Catholic and Orientalist, reached similar conclusions. However, he attributed only Ezra 1-10 to the Chronicler. Movers had studied theology in Münster and was then professor of Old Testament theology in the Catholic faculty at Breslau (now Wrocław) from 1839 to his death. He had interest in the Phoenicians and in the two recensions of the Book of Jeremiah, the Masoretic text and the Greek text of the Septuagint. ${ }^{40}$ Movers was at the same time concerned with Ancient Near Eastern history, text criticism and comparative philology. All these elements would play a role in his ensuing study of Chronicles.

Among Wellhausen's followers who doubted the historical trustworthiness of Chronicles, we must mention Charles C. Torrey, historian, orientalist, archaeologist and founder of the American School of Archaeology in Jerusalem in 19001901, a very critical spirit. He taught Semitic languages at the Andover Theological Seminary (1892-1900) and at Yale University (1900-1932). He was also a specialist of the Koran. ${ }^{41}$ Here is a summary of his opinion on Chronicles: ${ }^{42}$

No fact of Old Testament criticism is more firmly established than this, that the Chronicler as a historian is thoroughly untrustworthy. He distorts facts deliberately and habitually, invents chapter after chapter with the greatest freedom, and what is most dangerous of all, his history is not written for its own sake, but in the interest of an extremely one-sided theory.

According to Torrey, and this was a common opinion at that time since Zunz, the Chronicler was also the author of Ezra-Nehemiah, and these works were unreliable from the point of view of history. This led to the complete denial of the return from the exile and the restoration of "Israel":

39 Cf. Japhet, “Historical Reliability,” 103, note 31.

40 Franz Karl Movers, Kritische Untersuchungen über die biblische Chronik. Ein Beitrag zur Einleitung in das Alte Testament (Bonn: T. Habicht, 1834). See Japhet, "Historical Reliability,” 103, note 32.

41 Charles Cutler Torrey, The Composition and Historical Value of Ezra-Nehemiah, BZAW 2 (Giessen: Ricker, 1896); Charles Cutler Torrey, The Chronicler's History of Israel: Chronicles-Ezra-Nehemiah Restored to Its Original Order (New Haven, CT: Yale University Press, 1954; Port Washington, NY: Kennicat Press, 1973); Charles Cutler Torrey, Ezra-Studies (Chicago, IL: University of Chicago Press, 1910).

42 Torrey, Composition, 52; cf. Japhet, "Historical Reliability,” 88. 
The exile was a limited phenomenon; there was no restoration at all; Ezra the Scribe is a fictitious figure; the edict of Cyrus and the letter of Artaxerxes are later forgeries; the story about the bringing of the Torah from Babylon is pure imagination; the expulsion of the foreign wives is an unfounded invention; and so on. ${ }^{43}$

This is probably one of the most scathing and disparaging opinions on Chronicles that we meet in our history of research.

Other scholars were less radical in their conclusions, for instance, Albin van Hoonacker (Bruges, 19 November 1857 - Bruges, 1 November 1933), a Roman Catholic theologian, professor at the Faculty of Theology of the Catholic University of Leuven (Belgium).$^{44} \mathrm{He}$ came to discuss the value of Chronicles in his dialogue with Abraham Kuenen, Graf and Wellhausen about the composition of the Pentateuch, a debate that caused him some difficulties with the Church authorities in Rome. Albin van Hoonacker raised doubts about the historical framework of Ezra-Nehemiah and he placed Ezra after Nehemiah. ${ }^{45}$ Albin van Hoonacker is also one of the scholars who used the Elephantine papyri in his research, an element of clear importance in the study of postexilic Israel. ${ }^{46}$

43 Torrey, Composition, 49-50; cf. Japhet, “Historical Reliability,” 90.

44 Albin van Hoonacker was appointed to a newly created chair, that of the Histoire critique de l'Ancien Testament, due to his involvement in the debate on the origin and authorship of the Pentateuch.

45 See Albin van Hoonacker, Néhémie et Esdras. Nouvelle hypothèse sur la chronologie de l'époque de la restauration (Gand: H. Engelcke, 1890); Néhémie en l'an 20 d'Artaxerxes I. Esdras en l'an 7 d'Artaxerxès II. Réponse à un mémoire de A. Kuenen (Gand: H. Engelcke, 1892); Zorobabel et le second temple. Étude sur la chronologie des six premiers chapitres du Livre d'Esdras (Gand: H. Engelcke, 1892); Nouvelles études sur la restauration juive après l'exil de Babylone (Paris: Leroux, 1896). See Japhet, “Historical Reliability,” 103, note 37. On Albin van Hoonacher, see Joseph Coppens, Le Chanoine Albin Van Hoonacker. Son enseignement, son œuvre et sa méthode (Paris: Desclée de Brouwer, 1935); Johan Lust, “A. van Hoonacker and Deuteronomy,” in Norbert Lohfink (ed.), Das Deuteronomium. Entstehung, Gestalt und Botschaft, BETL 68 (Leuven: Peeters, 1985), 13-23. On the discussions in this period, see, among many others, Richard Jude Thompson, Moses and the Law in a Century of Criticism since Graf, SVT 19 (Leiden: Brill, 1970), 89-90.

46 See Albin van Hoonacker, Une Communauté Judéo-Araméenne à Éléphantine, en Égypte aux VIe et Ve siècles av. J.-C., The Schweich Lectures (London: British Academy, 1915). The discoveries at Elephantine surely created a surprise among scholars. See, for instance, Arthur Cowley, Aramaic Papyri of the Fifth Century B.C. (Oxford: The Clarendon Press,1923; Eugene, OR: Wipf \& Stock Publishers, 2005), xxiii: "So far as we learn from these texts Moses might never have existed, there might have been no bondage in Egypt, no exodus, no monarchy, no prophets. There is no mention of other tribes and no claim to any heritage in the land of Judah. Among the numerous names of colonists, Abraham, Jacob, Joseph, Moses, Samuel, David, so common in later times, never occur (nor in Nehemiah), nor any other name derived from their past history as recorded in the Pentateuch and early literature. It is almost incredible, but it is true." 
Along the same line and in a neighboring country, in the Netherlands, Willem Hendrik Kosters (Enschede 1843 - Enscede 1897), a colleague of Kuenen in Leiden, came to somewhat more radical conclusions. For instance, he questioned the historicity of the restoration (cf. Torrey) and the reliability of Ezra 1-4. ${ }^{47}$

\section{Change in Perspective: Archaeology and Assyriology}

With Charles Torrey, we may have reached a nadir in the exegesis of Chronicles. The books are unreliable for the historian, disappointing for the theologian and dreary for the literary critic. As several other cases, a change in perspective comes both from internal developments and external factors. In the nineteenth century, the main interest was more history than literature and theology. The study of both the Pentateuch and Chronicles was guided by the search for reliable sources in the reconstruction of a history of Israel. Wellhausen's major work was entitled Prolegomena zur Geschichte Israels, and this title is revelatory of his intention.

In the course of the nineteenth century, however, an important shift in perspective occurred because of the numerous archaeological discoveries, especially in Israel, in Egypt and in Mesopotamia. Newly deciphered documents and new architectural elements obliged scholars to revise and complement the pieces of information coming from the Bible alone. As for the postexilic period, the discovery of the Elephantine papyri around 1870 is of paramount importance. ${ }^{48}$ These discoveries obliged scholars to revise their opinions on the postexilic period and, consequently, on the value of Chronicles as witness of the spirit of that time. The

47 Willem Hendrik Kosters, Het herstel van Israël in het Perzische tijdvak. Eene studie (Leiden: E.J. Brill, 1893) = Die Wiederherstellung Israels in der persischen Periode. Übersetzt von A. Basedow (Heidelberg: Hörning, 1895). See Japhet, "Historical Reliability,” 103, note 37.

48 See, for instance, among the first publications on this topic, Martin Sprengling, Chronological Notes from the Aramaic Papyri; the Jewish Calendar; Dates of the Achaemenians (Cyrus-Darius III), Miscellanea papyrorum Elephantine 11 (Chicago, IL: University of Chicago Press, 1911); Eduard Sachau, Aramäische Papyrus und Ostraka aus einer jüdischen Militär-Kolonie zu Elephantine. Altorientalische Sprachdenkmäler des 5. Jahrhunderts vor Chr. (Leipzig: Hinrichs, 1911); Stanley A. Cook, "The Significance of the Elephantine Papyri for the History of Hebrew Religion," The American Journal of Theology 19/3 (1915): 346-82; Albin van Hoonacker, Une Communauté Judéo-Araméenne à Éléphantine, en Égypte aux VIe et Ve siècles av. J.-C. (London: Oxford University Press, 1915). For a more recent treatment of the documents, see Bezalel Porten, with J.J. Farber, C.J. Martin, G. Vittman (eds.), The Elephantine Papyri in English: Three Millennia of Cross-Cultural Continuity and Change, (Leiden: Brill, 1996; Atlanta, GA: Society of Biblical Literature, 2011). 
Elephantine papyri provided exegetes and orientalists with fresh information about the Persian period and about a Jewish community of the diaspora. Until then, the Bible was almost the only source of information about the postexilic period. Now, documents were revealing important aspects of society, law, justice and religion, and details about Jerusalem, the temple, the Persian authorities, and the celebration of some liturgical feasts, for instance Passover. These papyri shed new light on the content of Ezra-Nehemiah, and conversely also on Chronicles.

One of the first authors who is witness to this shift in perspective is probably the Assyriologist Hugo Winckler, professor at the University of Berlin. ${ }^{49} \mathrm{He}$ is famous for having excavated the Hittite capital Hattuša, close to Boğazköy, in Turkey, from 1906 onward. He is also renowned for his translation of the Code of Hammurabi and the letters from Tel-Amarna. As a specialist of cuneiform documents, he was persuaded that these materials would force historians to revise their image of the history of the Ancient Near East. ${ }^{50}$ As for Chronicles, Winckler remained cautious, but admitted that the negative views of his predecessors were exaggerated in several aspects.

He acknowledged, however, the general view that Chronicles is prejudiced and tendentious in most cases. He limited his inquiry, therefore, to a very restricted number of texts, the sections unique to Chronicles, i. e. the material added to Samuel-Kings. Even in this case, he put the texts under close scrutiny and used them only when they proved to be free from historical biases. More importantly, Winckler was convinced that the new discoveries in the Ancient Near East had a special bearing on "historical reliability" or "historical probability" and that these new elements had some consequences for the way of reading Chronicles as well. ${ }^{51} \mathrm{This}$ attitude brought about a change in mentality in the field and, in particular, scholars ceased to disqualify Chronicles a priori as a source of information about the postexilic period. Comparison with other sources and further inquiries became indispensable.

49 Among Hugo Winckler's chief publications, mention must be made of Keilinschriftliches Textbuch zum Alten Testament, Hilfsbücher zur Kunde des Alten Orients 1 (Leipzig: J.C. Hinrichs'sche Buchhandlung, 1892, ${ }^{31909) ; ~ D i e ~ G e s e t z e ~ H a m m u r a b i s ~ i n ~ U m s c h r i f t ~ u n d ~ U ̈ b e r s e t z u n g, ~ D e r ~ A l t e ~}$ Orient 4 (Leipzig: J.C. Hinrichs'sche Buchhandlung, 1904).

50 See his significant work in the field, Der alte Orient und die Geschichtsforschung, Mitteilungen der Vorderasiatischen Gesellschaft 11,1 (Berlin: Wolf Peiser, 1906). See also "Zur Geschichte und Geographie Israels” in Altorientalische Forschungen (Helsingfors: Verlag von Eduard Pfeiffer, 1902), 249-73.

51 See Hugo Winckler, "Bemerkungen zur Chronik als Geschichtsquelle,” Alttestamentliche Untersuchungen (Helsingfors: Verlag von Eduard Pfeiffer, 1891), 157-67; cf. Japhet, "Historical Reliability," 91. 
After Winckler, several scholars treated Chronicles with more sympathy, for instance Immanuel Benzinger and Rudolf Kittel in Germany, or Edward Lewis Curtis and Albert Alonzo Madsen in the United States. ${ }^{52}$ Archaeology had a definite place in these publications since Immanuel Benzinger (Stuttgart, 1865 - Riga, 1935), for instance, travelled to Palestine and taught in Jerusalem. He participated in the revision of the Baedeker for Palestine and Syria. Rudolf Kittel (1853-1929), active in Tübingen, Breslau (Wrocław), and Leipzig, also studied the archives of El-Amarna and the Code of Hammurabi. He is more famous for his Biblia Hebraica, but he also published on the history and the religion of Israel. He was rather conservative and opposed to Wellhausen's opinions. ${ }^{53}$

But things change slowly, and this is evident in the case of William Foxwell Albright (1891-1971), to take just one example. ${ }^{54}$ He held the traditional view about the unreliability of Chronicles, as it is confirmed by the following statement:

Up to the present no archaeological discoveries have confirmed the facts added by the Chronicler to his liberal excerpts from the canonical books of the Old Testament. Some of his statements, especially his lists of towns and clans, have doubtless historical value, though their exact source remains unknown [...] It is still however too early for a categorical denial of historical nuclei in these fantastic stories $[\ldots]^{55}$

52 See Immanuel Benzinger, Die Bücher der Chronik, KHAT (Tübingen und Leipzig: J.C.B. Mohr [Paul Siebeck], 1901), xxiii; Rudolf Kittel, Die Bücher der Chronik, HAT (Göttingen: Vandenhoeck \& Ruprecht, 1902), $\mathrm{x}$-xvi; English Translation: The Books of the Chronicles (Baltimore, MD: The Johns Hopkins Press; London: David Nutt, 1895); Edward Lewis Curtis and Albert Alonzo Madsen, A Critical and Exegetical Commentary on the Books of Chronicles, ICC (Edinburgh: T\&T Clark, 1910, 1976), 14-6. Cf. Japhet, "Historical Reliability,” 91 and 104, note 44.

53 See Rudolf Kittel, Geschichte der Hebräer. 2 vol. 1. Quellenkunde und Geschichte der Zeit bis zum Tode Josuas. 2. Quellenkunde und Geschichte der Zeit bis zum babylonischen Exil (Gotha: Perthes, 1888-1892; ${ }^{21909-1912 ;}{ }^{31922-1923) ; ~ G e s c h i c h t e ~ d e s ~ V o l k s ~ I s r a e l . ~ B a n d ~ 1 . ~ P a l a ̈ s t i n a ~ i n ~}$ der Urzeit, Das Werden des Volkes, Geschichte der Zeit bis zum Tode Josuas (Stuttgart: Kohlhammer, 1932); Band 2. Das Volk in Kanaan, Geschichte der Zeit bis zum babylonischen Exil (Stuttgart: Kohlhammer, 1925); Band 3. Die Zeit der Wegführung nach Babel und die Aufrichtung der neuen Gemeinde (Stuttgart: Kohlhammer, 1929); Die Religion des Volkes Israel (Leipzig: Quelle und Meyer, 1921).

54 On Albright, see, for instance, David Noel Freedman, Robert B. MacDonald, and Daniel L. Mattson, The Published Works of William Foxwell Albright: A Comprehensive Bibliography (Cambridge, MA: American Schools of Oriental Research, 1975); Gus W. van Beek, The Scholarship of William Foxwell Albright: An Appraisal (Atlanta, GA: Scholars Press, 1989); Peter Douglas Feinman, William Foxwell Albright and the Origins of Biblical Archaeology (Berrien Springs, MI: Andrews University Press, 2004); Thomas Levy and David Noel Freedman, William Foxwell Albright 1891 1971: A Biographical Memoir (Washington, DC: National Academy of Sciences, 2008).

55 William Foxwell Albright, “The Date and Personality of the Chronicler,” JBL 40 (1921): 104-24, here 104 , note 1 . 
Albright had access to the newly discovered and edited Elephantine documents. ${ }^{56}$ For this reason, he was ready to revise his negative judgment in the hope of finding new elements to confirm the validity of a research that would take Chronicles into account as one of the key elements in a description of the postexilic Israel's worldview. We are now in a troubled and frantic period between the two World Wars, mainly in Europe. This is also a time of heated discussions in political and academic circles about radical and totalitarian ideologies. This atmosphere had an impact on biblical exegesis as well. ${ }^{57}$ As for Chronicles, the main developments took place in Germany with Gerhard von Rad and Martin Noth.

\section{Change in perspective: History "wie es gewesen war" or "wie es geschrieben ist"? - Gerhard von Rad}

[Die Chronik] schildert nicht "wie es gewesen,” sondern pragmatisch; die Logik der Ereignisse, der Zusammenhang von Ursache und Wirkung wird unbedenklich zerschnitten, sei es, daß die eigentlichen Wirkungen von Ereignissen fehlen, sei es, daß weitgehend für Wirkungen theoretisch Ursachen erdichtet werden. ${ }^{58}$

Chronicles does not depict the events "as they happened," but in a pragmatic way. The logic of the events, the connection between cause and effect, is cut without much scruple, either since the effects of the events are missing, or since causes are concocted, theoretically and to a large extent, for the effects.

This reflection by Gerhard von Rad marks a turning-point in the history of research on Chronicles. ${ }^{59}$ Everyone has noticed the quotation of Leopold von Ranke's famous saying that the historian should report the events "wie es eigentlich gewesen war," without introducing personal, moral or philosophical, considerations into the presentation of the facts. Consciously or not, previous generations

56 Albright, "Date," 107, 117-8.

57 See, among others, Horst Junginger, The Study of Religion under the Impact of Fascism, Numen Book Series 117 (Leiden - Boston: Brill, 2008).

58 Gerhard von Rad, Das Geschichtsbild des chronistischen Werkes, BWANT 54 (Stuttgart: Kohlhammer, 1930), 2.

59 For more details, see, for instance, Gerhard von Rad, From Genesis to Chronicles: Explorations in Old Testament Theology (ed. Kenneth C. Hanson), Fortress Classics in Biblical Studies (Minneapolis, MN: Fortress, 2005). On Gerhard von Rad, see especially Smend, Kritiker und Exegeten, 794-824. 
of exegetes condemned Chronicles for being biased, tendentious, ideological and therefore for not corresponding to Ranke's ideal of history writing. Gerhard von Rad is aware of the problem, obviously, but he focuses his study precisely on the Chronicler's ethical and religious background that characterizes his work. He speaks of the Chronicler's "image of history" (Geschichtsbild) and of "tendency" (Tendenz). Another quotation is of great significance:

\begin{abstract}
Man weiß, daß der Chronist den Ablauf der geschichtlichen Ereignisse nach eigenem Willen weithin neu geformt hat, teils nach Maßgabe vorhandener zeitgenössischer Verhältnisse, teils seinen eigenen noch nicht realisierten Tendenzen entsprechend.

One knows that the Chronicler reshaped the course of the historical events by and large according to his own will, partly in relation to contemporaneous existing situations, partly in correspondence with his tendencies that had not yet become reality.
\end{abstract}

Gerhard von Rad adds a final, concluding, reflection about the Chronicler's way of writing history:

[...] dann verschwimmt die von uns heutigen schärfer empfundene Grenze zwischen objektiver historischer Tatsache und später eingetragener Deutung oder gar Korrektur.

[...] therefore, the borderline between objective historical fact and interpretation, later introduced, or even correction, tends to disappear, a borderline which is perceived more acutely by us today.

These quotations reveal von Rad's sensitivity for a type of history that departs from the tenets of an ideal, objective history that was dominant in the $19^{\text {th }}$ century and linked especially with the names of Leopold von Ranke (1795-1886) and Theodor Mommsen (1817-1903), a history based not on ideas but on a rigorous examination of documents. ${ }^{60}$ The Chronicler, on the contrary, rarely distinguishes facts from interpretation, and this is the reason why the exegesis of the $19^{\text {th }}$ century had little appreciation for this kind of "history." As we saw, von Rad is interested, instead, precisely in what characterizes the Chronicler's interpretation of history. For

60 On this, see, among others, Andreas D. Boldt, The Life and Work of the German Historian Leopold von Ranke (1795-1886): An Assessment of His Achievements (Lewiston, NY: Edwin Mellen Press, 2015). On the evolution in the field of the history of Israel, see Richard S. Hess, "Introduction: Foundations for a History of Israel," in Ancient Israel's History: An Introduction to Issues and Sources, eds. Bill T. Arnold and Richard S. Hess (Grand Rapids, MI: Baker Academic, 2014), 1-22; Jean Louis Ska, "Questions of the 'History of Israel' in Recent Research," in Hebrew Bible/ Old Testament. The History of Its Interpretation. Volume III. From Modernism to Post-Modernism (The Nineteenth and Twentieth Centuries). Part 2. The Twentieth Century - From Modernism to Post-Modernism [hereafter HBOT III.2], ed. Magne Sæbø (Göttingen: Vandenhoeck \& Ruprecht, 2014), 391-432. 
instance, he inquires about the way the Chronicler speaks of God, the people of Israel, the law, and how he retells Israel's history from the beginning until David.

In this, von Rad is close to a new way of understanding historical research that is aware of the fact that objective history does not exist as such since, on the one side, facts are always documented facts, necessarily seen and interpreted through the lens of the witnesses, and, on the other, that there is no history without the positive contribution of the historian who unravels the connections between facts and introduces a logic in the mere chronological succession of events. History is a reconstruction, according to Wellhausen's famous saying: “Konstruiren muß man bekanntlich die Geschichte immer [...]. Der Unterschied ist nur, ob man gut oder schlecht konstruirt" - "But history, it is well known, should always be constructed [...]. The question is whether one constructs well or not."61

This view of history is not completely new. Let me mention at least two names. The first personality to be remembered is that of the Swiss historian Jacob Burckhardt (Basel, 1818-1897). ${ }^{62}$ He had studied in Berlin under Leopold von Ranke, but soon became interested in culture and civilization, especially in the history of art, without neglecting economical and political developments, however. He is famous for his history of the Italian Renaissance. ${ }^{63}$ Jacob Burckhart was in contact with Wilhelm de Wette who started teaching theology in Basel in 1822, and was appointed more than once as rector of the university. Actually, Jacob Burckhardt who was studying theology decided to shift to history because de Wette's esprit critique shuddered the foundations of his religious convictions. ${ }^{64}$ What matters for our topic is that Jacob Burckhardt is exemplary of a shift in historical research that reconciles history with art and culture. This new spirit would suffuse the academic world especially after the First World War and would influence the studies on Israel's history in general and the Book of Chronicles in particular, and this in a direct or indirect manner.

61 Julius Wellhausen, Prolegomena zur Geschichte Israels (Berlin: Reimer ${ }^{2} 1883$; repr. Berlin: de Gruyter 2001), 365. English translation: Prolegomena to the History of Israel, Reprints and Translations (Atlanta, GA: Scholars Press 1994), 367.

62 On Burckhardt, see, for instance, René Teuteberg, Wer war Jacob Burckhardt? (Basel: Druckerei Ganzmann, 1997); Stefan Bauer, Polisbild und Demokratieverständnis in Jacob Burckhardts «Griechischer Kulturgeschichte», Beiträge zu Jacob Burckhardt 3 (Basel: Schwabe - München: C. H. Beck, 2001).

63 Jacob Burckhardt, Die Cultur der Renaissance in Italien: Ein Versuch (Basel: Schweighauser, 1860); Geschichte der Renaissance in Italien (Stuttgart: Vlg. Ebner \& Seubert, 1878).

64 On this point, see Thomas Albert Howard, Religion and the Rise of Historicism: W. M. L. de Wette, Jacob Burckhardt, and the Theological Origins of Nineteenth-Century Historical Consciousness (Cambridge: Cambridge University Press, 1999, 2009). 
The second name is that of Karl Gotthard Lamprecht (25 February 1856 Jessen 10 May 1915 Leipzig) who taught for a long time in Leizpig and published a History of Germany in twelve tomes and nineteen books. ${ }^{65}$ He reacted strongly against the Neo-Rankian historians who were too much interested in important events of national and international politics. He developed his own vision of history in several writings, enhancing the importance of society, culture and economy which were for him more important than political and personal history. ${ }^{66}$ Albrecht Alt and Noth studied in Leipzig, and von Rad taught in this university as Privatdozent, from 1930 till 1934. Whether they came in touch with Lamprecht's vision of history is difficult to determine with certainty. There is however a certain parenthood between, for instance, von Rad's interest in the main cultural and religious conceptions underlying the Chronicler's work and Lamprecht's insistence on cultural history.

Burckhardt and Lamprecht were forerunners of a movement that took shape in France after the end of the First World War, the well-known École des Annales ("The Annals School"). In a few words, the tragic experience of the First World War showed that history is not only written by kings, emperors, or heads of states, in royal courts or on battlefields. The real subject of history is the life of the peoples, especially in its social and economic aspects. Developments, in this field, are much slower than in a history focused on specific political or military events. The historians belonging to this school distinguish therefore the histoire événementielle ("history of events") from the histoire de moyenne or longue durée ("medium or long term history”). This second kind of history pays attention to slow evolutions linked with changes in climate, techniques, economy, and society. The attention shifted from the royal courts and battlegrounds to the mentalities and conditions of daily life. These historians also introduced new quantitative methods to measure with more precision the evolution of societies or human groups. The important names are those of Marc Bloch (1886-1944), Lucien Fèbvre (1878-1956), Fernand Braudel (1902-1985), George Duby (1919-1996) and Jacques Le Goff (1924-2014). We may add to this group the Belgian scholar Henri Pirenne (1862-1935). ${ }^{67}$

65 Karl Gotthard Lamprecht, Deutsche Geschichte. Zwölf Bände in neunzehn Büchern (Berlin: Hermann Heyfelder \& Weidmannsche Buchhandlung, 1906-1911).

66 Karl Gotthard Lamprecht, Alte und neue Richtungen in der Geschichtswissenschaft (Leipzig: Gaertner, 1896); Die kulturhistorische Methode (Berlin: Gaertner, 1900).

67 On this school, see Peter Burke, The French Historical Revolution: The Annales School 1929-89 (Stanford, CA: Stanford University Press, 1990); André Burguière, L'École des Annales. Une histoire intellectuelle (Paris: Odile Jacob, 2006); English translation: Annales School: An Intellectual History (Ithaca, NY: Cornell University Press, 2009); François Dosse, “ À l'école des Annales, une règle: l'ouverture disciplinaire,” Hermès 67 (2013): 106-12. Among the precursors of this school, we may count, in France, Voltaire, in his Nouvelles considérations sur l'histoire (1744); François 
Naturally, it is difficult if not impossible to trace a direct influence of the Annales School on the exegesis of Chronicles. Nonetheless we may safely affirm that the academic atmosphere was different when Gerhard von Rad published his pamphlet on these biblical books. As we could see, his viewpoint is less positivistic than that of the former generation and he is also less negative in his judgment because, at that time, scholars were more sensitive to other aspects of history-writing. According to this new vision, ancient historians, and this holds true for ancient Israelite "historians," through their recording of the past present a way of understanding the roots of the present and of shaping (or of trying to shape) it accordingly. The cultural, moral, ideological, and theological background of both the writers and the audience are essential elements of these "histories."

All this was made partly possible because the discussions about the composition of the Pentateuch and the relative chronology of the different sources had come to a - relative - rest. Hermann Gunkel, the formgeschichtliche Schule and the Religionsgeschichtliche Schule had introduced new questions and opened new areas of research, especially about the oral origins of ancient Israel's traditions. ${ }^{68}$ History or historical "truth" was no longer the major or the unique focus of interest in biblical studies.

More importantly, perhaps, and easier to determine, is the impact of the political situation on von Rad's research. His monograph on Chronicles was published in 1930 when he was Privatdozent at Leipzig, a university where he had studied under the guidance of Albrecht Alt (1883-1956). Already at that time, von Rad was concerned by the anti-Semitic and anti-Old Testament bias that began to creep in among German scholars and he reacted in defending the vital significance of the Old Testament for Christian faith. ${ }^{69}$ As a disciple of Karl Barth and as an expert in dialectic theology, he insisted on the religious value of every part of the Old Testament, and this is probably the reason why he wrote an essay on Chronicles, a book that was often presented as a compendium of Jewish legalism and ritualism. ${ }^{70} \mathrm{He}$ did not look for "hard facts" in Chronicles, but for an expression of Israel's deep convictions.

Guizot, Histoire générale de la civilisation en Europe (1828) and François-René de Chateaubriand, Études historiques (1832). All of them insist on the social and economic aspects of history.

68 See, for instance, Japhet, "Historical Reliability," 96-7.

69 On this point, but more on Gerhard von Rad's career in Jena (1934-1945), see Bernard M. Levinson, "Reading the Bible in Nazi Germany: Gerhard von Rad's Attempt to Reclaim the Old Testament for the Church,” Interpretation: A Journal of Bible and Theology 62 (2008): 238-54. As it is well-known, National-Socialism took power in 1933 in Germany.

70 On the influence on Karl Barth, see John Barton, "Karl Barth and the Canonical Approach," in HBOT III.2, 101-8; Manfred Oeming, "Karl Barth," HBOT III.2, 174-81. 
All in all, the Chronicler has a theological, dogmatic and didactic purpose, namely to legitimate the cult of the Second Temple trough a "David-Arch (of covenant)-Levites-tradition."71 This cult is centered not on sacrifice and expiation, but on praise and gratitude for God's promised grace. ${ }^{72}$ Von Rad's ideas were influential especially because they highlighted the positive side of the Chronicler's message.

\title{
8 Change in perspective: The Chronicler, a historian "in his own right" according to Martin Noth
}

We follow the same line when coming to Noth, the direct successor of von Rad. ${ }^{73}$ He went along with his predecessor in many respects. For instance, he insisted on the necessity to judge the Chronicler "in his own right" and according to the literary standards of his time. The following paragraph is telling in this regard: ${ }^{74}$

\begin{abstract}
In all the features of Chr.'s composition discussed so far, no so-called bias (Tendenz) is to be perceived. They lead us, rather, to the conclusion that Chr. was always making an effort to go beyond the Vorlagen at his disposal by enlivening and giving graphic portrayal to the historical narrative. As is only to be expected, he sought to achieve this aim by making use of the conceptual horizon and interests of his own day, for there was no possibility of his giving a faithful historical picture of those older times which he had in view at any given moment. However, in the interests of an accurate appraisal of Chr.'s work it is also important to appreciate that he deserves recognition as an independent narrator in his own right. His work manifestly displays a purely literary concern, and this concern has influenced the content of his historical presentation in matters of detail. [...] His aim was not to entertain but to give teaching about various specific consequences which could be drawn from past history and which were of relevance to the present.
\end{abstract}

71 Von Rad, Geschichtsbild, 134.

72 Von Rad, Geschichtsbild, 136.

73 On Martin Noth, see Smend, Kritiker und Exegeten, 825-846.

74 Martin Noth, The Chronicler's History. Translated by H.G.M. Williamson with an Introduction, JSOT.S 50 (Sheffield: JSOTPress, 1987), 80. The German original is the second part of Die Überlieferungsgeschichtliche Studien. Die sammelnden und bearbeitenden Geschichtswerke im Alten Testament, SKGG 18,2 (Halle [Saale]: Niemeyer, 1943; Tübingen: Niemeyer, 1957; Darmstadt: Wissenschaftliche Buchgesellschaft: ${ }^{31967)}$ entitled Das chronistische Geschichtswerk. 
Noth's appraisal of the Chronicler's work is the exact opposite of that of Torrey on two main points. First, Noth highlights the narrative and literary qualities of his work, trying to understand its real purpose instead of looking only for "objective history." Second, Noth emphasises the Chronicler's didactic intention. The Chronicler purports neither to entertain nor to inform about the past as such. His intention is definitely to draw useful lessons from the past for his contemporaries.

Another point in Noth's research may have importance, namely his attention to the function of discourses in the Chronicler's writings. Discourses by important personalities were also determinative in the Deuteronomistic History. In this respect, we find close parallels between biblical literature and ancient historical works, especially in classical Greek and Roman histories. ${ }^{75}$ Discourses were often used by ancient historians to convey their own vision in specific fields. ${ }^{76}$

Noth is more interested in historical and literary questions than von Rad. He inquires about the original form of the text, its sources, and its dating before coming to its literary characteristics, its historical presuppositions, its reworking of its sources and, eventually, its theology. In his conclusion, he explicitly parts ways with von Rad about the theology of the book. For Noth, the Chronicler's work was composed to defend Jerusalem as the unique legitimate cultic centre for all Israel over against the claims of the Samaritans. ${ }^{77}$ Therefore, Chronicles is more historical than merely theological. Noth insists on the Chronicler's "clear intention of giving information about what really happened" - "seine[...] offenkundige [...] Intention, wirklich Geschehenes mitzuteilen."78 We hereby return to a vision of

75 On this point, see Kenneth G. Hoglund, "The Chronicler as Historian. A Comparative Perspective," in The Chronicler as Historian, eds. M. Patrick Graham, Kenneth G. Hoglund and Steven L. McKenzie, JSOT.S 238 (Sheffield: Sheffield Academic Press, 1997), 19-29, who explores the elements common to Chronicles and Hellenistic historiography. On discourses in Chronicles as such, see Mark A. Throntveit, "The Chronicler's Speeches and Historical Reconstruction," in The Chronicler as Historian, 225-45. For a short bibliography on the topic, see 227, note 9. On the role of discourses in classical literature, see, among others, N.P. Miller, "Discourses. Dramatic Speech in the Roman Historians," Greece \& Rome 22 (1975): 45-57; Cynthia Damon, "Rhetoric and Historiography," in A Companion to Roman Rhetoric, ed. W. Dominik and J. Hall (Oxford: Blackwell Publishers, 2006), 439-50; Cristina Pepe, The Genres of Rhetorical Speeches in Greek and Roman Antiquity, International Studies in the History of Rhetoric 5 (Leiden: Brill, 2013). In the New Testament, see Martin Dibelius, “The Speeches in Acts and Ancient Historiography," in Studies in the Acts of the Apostles, ed. E. Greenwen (New York: Charles Scribner's Sons, 1956), 138-45.

76 The most famous example is, probably, Pericles' funeral oration in Thucydides' History of the Peloponnesian Wars, 2.35-46.

77 Noth, Chronicler's History, 97-8.

78 Noth, Chronicler's History, 98; German original: Überlieferungsgeschichtliche Studien, 172. 
Chronicles as a historical work and to a conception of history closer to that of von Ranke, although surely not in the modern sense of the word, because Chronicles "believed [...] that only in this way would he be able to serve the concerns of his own time."79 History is the only valid way of authenticating the institutions of the Second Temple period.

This discussion between von Rad and Noth is more than a typical example of different attitudes or different temperaments. From the very beginning of the exegesis of Chronicles, we find two main directions in the history of research. On the one side, some scholars read more theology (or ideology) than history in Chronicles, whereas others look at Chronicles as mainly a work of history. This was already the case with David Qimhi (ca.1160-1235) and Isaac ben Jehuda Abravanel (1437-1508), as we saw earlier. This same contrast is observable in two more recent collective publications, The Chronicler as Historian ${ }^{80}$ and The Chronicler as Theologian ${ }^{81}$.

It is perhaps of some interest to know that North published this short monograph in 1943. He served in the Wehrmacht (military) during the Second World War from 1939 till 1941, and again from 1943 until 1945. He therefore wrote this book in Königsberg (today Kaliningrad) between two periods of military service.

\section{Change in Perspective: Literarkritik and Literary Criticism - Source and Discourse}

A second element contributed to a change in mentality, namely the growing importance of literary studies on biblical texts. Already in 1938, in his well-known

79 Noth, Chronicler's History, 98.

80 Patrick M. Graham, Kenneth G. Hoglund and Steven L. McKenzie (eds.), The Chronicler as Historian, JSOT.S 238 (Sheffield: Academic Press, 1997). See also Isaac Kalimi, An Ancient Israelite Historian: Studies in the Chronicler, His Time, Place and Writing, Studia Semitica Neerlandica 46 (Assen: Van Gorcum, 2005); Sara Japhet, "Chronicles: A History,” in Das Alte Testament. Ein Geschichtsbuch? Beiträge des Symposiums "Das Alte Testament und die Kultur der Moderne," anläßlich des 100. Geburtstag Gerhard von Rads, eds. Erhard Blum, William Johnstone and Christoph Markschies, Altes Testament und die Kultur der Moderne 10 (Münster: Lit Verlag, 2005), 129-46.

81 Patrick M. Graham, Steven L. McKenzie and Gary N. Knoppers (eds.), The Chronicler as Theologian: Essays in Honor of Ralph W. Klein, JSOT.S 371 (London: T\&T Clark, 2003). See also John Goldingay, “The Chronicler as a Theologian,” Biblical Theology Bulletin 5 (1975): 99-126. 
essay, Das formgeschichtliche Problem des Hexateuchs, ${ }^{82}$ von Rad stated that "So far as the analysis of source documents is concerned, there are signs that the road has come to a dead end."83 This is the reason why he decided to ask central questions about the "final form [of the Hexateuch] as we have it" ${ }^{84}$ We find a similar reflection in his work on Chronicles, when he criticizes Wilhelm J. Rothstein's commentary because of an overstated interest in sources, layers, additions, etc. that reduces the book to a "Unsumme von disjecta membra" - "a vast sum of disjecta membra." 85 According to von Rad, the imperative of a theological interpretation as well as of historical research is to supplement this analytical process with an effort of understanding synthetically the biblical work ("das Bemühen um ein synthetisches Verstehen des Schriftwerkes)."86

The studies on the "final form" of the text had some forerunners, for instance Richard G. Moulton, who specialized in the study of Shakespeare ${ }^{87}$ before publishing several monographs on a literary reading of the Bible. ${ }^{88}$ Gunkel also had a strong influence since he shifted the attention from the genesis of the text to its original, oral, form and its typical style. For Gunkel, we may note, "exegesis is more an art than a science" and literary questions are much more important

82 Gerhard von Rad, Das formgeschichtliche Problem des Hexateuchs, BWANT 78 (Stuttgart: Kohlhammer, 1938); reprinted in Gesammelte Studien zum Alten Testament, TB 8 (München: Kaiser Verlag, 1958), 9-86; English translation: "The Form-Critical Problem of the Hexateuch," in The Problem of the Hexateuch and Other Essays (New York: McGraw-Hill, 1966; London: SCM, 1984), 1-78.

83 Von Rad, "Form-Critical Problem," 1.

84 Von Rad, "Form-Critical Problem," 1. The German expression for "final form" is Letztgestalt or Endgestalt.

85 Von Rad, Geschichtsbild, 133. The commentary discussed is by Wilhelm J. Rothstein, Kommentar zum ersten Buch der Chronik, KAT 18.2 (Leipzig: Deichert, 1927).

86 Von Rad, Geschichtswerk, 133.

87 Richard G. Moulton, Shakespeare as a Dramatic Artist: A Popular Illustration of the Principles of Scientific Criticism (Oxford: Clarendon Press, 1885). See also The Ancient Classical Drama: A Study in Literary Evolution Intended for Readers in English and in the Original (Oxford: The Clarendon Press. 1890).

88 Richard G. Moulton, The Literary Study of the Bible: An Account of the Leading Forms of Literature Represented in the Sacred Writings (London: Ibister and Company, 1896). See also Select Masterpieces of Biblical Literature (New York: The Macmillan Company; London: Macmillan \& Co., 1901); A Short Introduction to the Literature of the Bible (Boston, MA: D. C. Heath \& Co., 1901); The Modern Reader's Bible Translation (New York: The Macmillan Company, 1907); The Bible at a Single View. With an Appendix, How to Read the Bible (New York: The Macmillan Company, 1918). On this author, see Sarah Lawall, "Richard Moulton and the 'Perspective Attitude' in World Literature," in The Routledge Companion to World Literature, eds. Theo D'haen, David Damrosch and Djelal Kadir (London: Routledge, 2011), 32-40. 
than historical questions. ${ }^{89}$ Later on, in 1968, James Muilenburg delivered an impressive presidential address at the annual meeting of the Society of Biblical Literature, at Berkeley, California, on December 18, 1968. The text was published afterwards with the telling title: "Form Criticism and Beyond". ${ }^{90}$ In a few words, Muilenburg promoted a study of stylistic features and structural compositions of biblical texts, especially poetic texts. He proposed to call this method - but this is perhaps not the most felicitous appellation - "rhetorical criticism". Here is a short summary of his program:

Persistent and painstaking attention to the modes of Hebrew literary composition will reveal that the pericopes exhibit linguistic patterns, word formations ordered or arranged in particular ways, verbal sequences which move in fixed structures from beginning to end. Clearly, they have been skillfully wrought in many ways, often with consummate skill and artistry. It is also apparent that they have been influenced by conventional rhetorical practices. $^{91}$

In the exegesis of Chronicles, the attention to its specific style is witnessed by this outstanding remark found in Roddy Braun's commentary on Chronicles published in 1986: "[The Chronicler is] a person of much greater literary skill than usually attributed to him". ${ }^{92}$ Two important works developed this insight. The first follows the path traced by James Muilenburg. The article stems from Leslie C. Allen (Pasadena, CA) and is devoted to stylistic devices such as chiasm, inclusion, and key words in structuring narrative units in Chronicles. ${ }^{93}$ The second, by Rodney K. Duke (Appalachian State University, Boone, North Carolina), chooses a different direction, namely Aristotle's treatise on rhetoric and endeavors to apply these Greek categories to Chronicles. ${ }^{94}$ Classifying Chronicles as belonging to the genre of deliberative rhetoric, he analyses the text according to Aristotle's three basic modes of persuasion, the rational, the ethical and the emotional. Despite laudable efforts, it seems that this work was not entirely successful. ${ }^{95}$ We have

89 "Denn Exegese im höchsten Sinne ist mehr eine Kunst als eine Wissenschaft" (Hermann Gunkel, "Ziele und Methoden der Erklärung des Alten Testaments," in Reden und Aufsätze [Göttingen: Vandenhoeck \& Ruprecht, 1913], 11-29, here 14).

90 James Muilenburg, "Form-Criticism and Beyond," JBL 88 (1969): 1-18.

91 Muilenburg, "Form-Criticism," 18.

92 Roddy Braun, 1 Chronicles, WBC 14 (Waco, TX: Word Books, 1986), xxv, quoted by Kleinig, "Current Research," 49.

93 Leslie C. Allen, “Kerygmatic Units 1 \& 2 Chronicles,” JSOT 41 (1988): 21-36.

94 Rodney K. Duke, The Persuasive Appeal of the Chronicler: A Rhetorical Analysis, JSOT.S 88 (Sheffield: The Almond Press, 1990).

95 See Kleinig, “Current Research,” 49; Duke, “Recent Research,” 33-6. 
here two of the chief directions in the field of stylistic analysis. On the one side, scholars proceed intuitively and inductively, looking for devices and features observed mainly in Hebrew and Semitic pieces of literature or, on the other side, they adopt a more systematic and deductive method, consulting first handbooks of ancient or more recent rhetoric, and applying these categories to biblical texts, and to Chronicles in particular. ${ }^{96}$

One of the main consequences of this new way of reading Chronicles is the major attention to its techniques of composition. A significant title to be mentioned in this context is The Chronicler as Author: Studies in Text and Texture. ${ }^{97}$ The Chronicler is now an author, after being a historian and a theologian. To this internal development, that is, a new or renewed literary sensibility, we must add now another, external, factor, the discovery of the Dead Sea Scrolls.

\section{Change in Perspective: Qumran and Scribal Work}

The impact of the Dead Sea Scrolls was progressive, but also impressive. ${ }^{98}$ Scholars noticed, for instance, similarities between the biblical commentaries or biblical interpretations found in the Dead Sea Scrolls and some biblical texts. This was the case especially with Chronicles, and suddenly, the interest for these late writings grew very fast. Chronicles became soon a field of research for all those interested in scribal work, in Fortschreibung, and in "Rewritten Bible". Let us give some examples of these recent tendencies in research.

96 For more details on the literary approach to Chronicles, see Kleinig, "Current Research," 49-51.

97 Patrick M. Graham and Steven L. McKenzie (eds.), The Chronicler as Author: Studies in Text and Texture, JSOT.S 263 (Sheffield: Academic Press, 1999).

98 See, for instance, George J. Brooke, "The Books of Chronicles and the Scrolls from Qumran," in Reflection and Refraction: Studies in Biblical Historiography in Honour of A. Graeme Auld, eds. Robert Rezetko, Timothy H. Lim and W. Brian Aucker, SVT 113 (Leiden - Boston, MA: Brill, 2007), 35-48. See also Knoppers, I Chronicles 1-9, 52-5. 


\subsection{Text criticism}

Here is a statement by George Brooke that aptly summarizes the present situation:

[...] it seems as if the Chronicler worked from a text of Samuel other than that found in the MT. Cross long ago suggested that 'examination of the passages of the large Samuel manuscript $\left(4 Q \mathrm{QSam}^{\mathrm{a}}\right)$ which are paralleled in Chronicles gives direct evidence that the Chronicler often utilized an edition of Samuel closer to the tradition of the Cave IV scroll than to that which survived in the Masoretic recension. ${ }^{99}$

The Hebrew text of Chronicles is closer to the Qumran fragments and the Old Greek in minor and major points. ${ }^{100}$ The consequence is that we have here one more example of the importance of some versions, concretely of the Old Greek. Moreover, we have to admit that the differences between Samuel-Kings and Chronicles can be explained otherwise than by attributing them all to a biased and partisan work by the Chronicler. In the Pentateuch as well, we have some examples where the Old Greek may have preserved a different form of the text, as in Exodus 37-40. ${ }^{101}$ Is it just a case that these chapters describe the construction of the tent, Israel's sanctuary?

These observations bring momentum to Graeme A. Auld's mill who defends the idea that Chronicles does not depend on or rework the actual text of Samuel-Kings, but a different source, common to Samuel-Kings and Chronicles. ${ }^{102}$

99 Brooke, “Chronicles and Qumran,” 36. The reference to Cross' work is Frank Moore Cross, The Ancient Library of Qumran and Modern Biblical Studies (Garden City, NY: Doubleday, 1958; The Biblical Seminar 30; Sheffield: Sheffield Academic Press, ${ }^{31995), ~} 141$ (139 in Sheffield's third edition). Cf. also this reflection by F.M. Cross: "Among other things it means that we can control better the Chronicler's treatment of his sources. The usual picture painted of the Chronicler violently or willfully distorting Samuel and Kings to suit his fancy must be radically revised." See Frank Moore Cross, "The History of the Biblical Text in the Light of Discoveries in the Judaean Desert,” HTR 57 (1964): 281-99, here 294, note 41.

100 See, among others, Knoppers, I Chronicles 1-9, 52-65 ("The Relevance of Text Criticism"). 101 See the fundamental article by Pierre-Maurice Bogaert, "L'importance de la Septante et $\mathrm{du}$ 'Monacensis' de la Vetus latina pour l'exégèse du livre de l'Exode (Chap. 35-40)," in Marc Vervenne (ed.), Studies in the Book of Exodus. Redaction - Reception - Interpretation, BETL 126 (Leuven: Peeters, 1996): 399-428.

102 See, for instance, Graeme A. Auld, Life in Kings: Reshaping the Royal Story in the Hebrew Bible, Ancient Israel and Its Literature (Atlanta, GA: Society of Biblical Literature, 2017). 


\subsection{Rewritten Bible}

The term "Rewritten Bible” - "umgeschriebene Bibel” - was introduced and popularized by Geza Vermes in 1961, in Scripture and Tradition in Judaism: Haggadic Studies. ${ }^{103}$ His point of departure was the Sefer ha-Jaschar, "The Book of the Righteous," an anonymous medieval, Jewish, book of circa the $11^{\text {th }}$ century, which retells the Pentateuch and the Book of Joshua, adding numerous midrashic and folkloristic elements. There are several definitions of "Rewritten Bible". ${ }^{104}$ Here is what Gary Knoppers offers in his commentary on Chronicles:

[This category refers to works] that take as point of departure an earlier biblical book or collection of books. They select from, interpret, comment on, and expand portions of a particular biblical book (or group of books), addressing obscurities, contradictions, and other perceived problems with the source text. Rewritten Bible texts normally emulate the form of the source and follow it sequentially. The major intention of such works seems to be to provide a coherent interpretative reading of the biblical text. ${ }^{105}$

The examples most frequently proposed by specialists in the field are, (1) outside of the Bible, Josephus' Jewish Antiquities; Pseudo-Philo's Liber Antiquitatum Biblicarum ("Book of Biblical Antiquities"); Joseph and Aseneth; and the Book of Jubilees; (2) in Qumran, Genesis Apocryphon; the Temple Scroll; Jeremiah Apocryphon; and Pseudo-Ezechiel; (3) in the Bible itself, 1-2 Chronicles; and 2 Maccabees; (4) in the New Testament, the Gospels of Matthew and Luke "rewriting" - to a certain extent - the Gospel of Mark.

This concept is close, but not completely identical with that of Inner-biblical exegesis, ${ }^{106}$ since it applies to longer texts or longer portions of texts. Inner-biblical

103 Geza Vermès, Scripture and Tradition in Judaism: Haggadic Studies, Studia Post-biblica 4 (Leiden: Brill, 1961, ${ }^{21973) . ~}$

104 For an overview on this term, see, for instance, George J. Brooke, "Rewritten Bible," in Lawrence Schiffman and James C. VanderKam (eds.), The Encyclopedia of the Dead Sea Scrolls (New York: Oxford University Press, 2000): 777-81; Moshe J. Bernstein, “'Rewritten Bible': A Generic Category Which Has Outlived Its Usefulness,” Textus 22 (2005): 169-96; József Zsengellér (ed.), Rewritten Bible after Fifty Years: Texts, Terms, or Techniques? JSJ.S 167 (Leiden: Brill, 2014); Daniel Stökl Ben Ezra, Qumran: Die Texte vom Toten Meer und das antike Judentum, UTB 4681 (Tübingen: Mohr Siebeck, 2016), 216-23. About Chronicles as 'Rewritten Bible,' see Knoppers, I Chronicles 1-9, 129-34 (“Chronicles: A Rewritten Bible?”). The answer is negative.

105 Knoppers, I Chronicles 1-9, 130; quoted by Jonker, “From Paraleipomenon to Early Reader," 224.

106 Concept popularized by Michael Fishbane, Biblical Exegesis in Ancient Israel (Oxford: Clarendon Press, 1985). For some clarification about the vocabulary, see Russell L. Meek, "Intertextuality, Inner-Biblical Exegesis, and Inner-Biblical Allusion: The Ethics of a Methodology,” Bib 95 (2014): 280-91. 
exegesis applies mostly to single elements or short sections. But there are zones of overlapping, obviously. The idea, or a similar idea, is developed, by Thomas Willi, Die Chronik als Auslegung. Untersuchungen zur literarischen Gestaltung der historischen Überlieferung Israels. ${ }^{107}$

Knoppers, among others, uses this concept in his commentary, but shows some dissatisfaction with the term because there is no clear definition of it. Moreover, Chronicles cannot be a "Rewritten Bible" because there was no "Bible" by the time Chronicles is put in writing. Besides this, Chronicles treats the Pentateuch and Samuel-Kings in a different way. The Pentateuch is already authoritative Scripture, whereas Samuel-Kings has less weight. Moreover, the first part of 1 Chronicles does not rewrite the corresponding parts in the Pentateuch and there are also important differences between Chronicles and its alleged "sources”. Ehud ben Zvi discusses the problem of applying the concept of "Rewritten Bible" to Chronicles at length and concludes in a negative way. ${ }^{108}$

A first quotation will clarify ben Zvi's position:

In fact, I worry on the basis of my reading that before too long the field will be flooded with references to Chronicles as "rewritten Bible" and this will become a cherished piece of our "widely shared knowledge." I suggest that we stop for a moment and reflect on the matter before it is too late. ${ }^{109}$

And here is his conclusion on the matter: ${ }^{110}$

Incidentally, some aspects of the relation of the book of Chronicles to Samuel-Kings or the Primary History in Persian Yehud may be heuristically approached by using an analogy of the relation between Deuteronomy and other legal pentateuchal material (especially what we call the Covenant Code) in the same Persian Yehud. In both cases, we are talking of co-existing texts, each with its own linguistic voice, and above all of a textually centered community of literati in which different ideological voices are seen as, and are meant to be seen as, complementary rather than exclusive of each other. Instead of Rewritten Bible, perhaps it is better to refer to texts as products of an ever evolving scripturing community.

107 Thomas Willi, Die Chronik als Auslegung. Untersuchungen zur literarischen Gestaltung der historischen Überlieferung Israels, FRLANT 106 (Göttingen: Vandenhoeck \& Ruprecht, 1972).

108 Ehud ben Zvi, "In Conversation and Appreciation of the Recent Commentaries by Steven L. Mckenzie and Gary N. Knoppers," in "New Studies in Chronicles: A Discussion of Two Recently Published Commentaries," ed. Melody D. Knowles, JHS 5 (2005): 21-45, esp. 31 -36 (“The Matter of the Rewritten Bible”). Sites: http://www.jhsonline.org and http://purl.org/jhs.

109 Ben Zvi, "Conversation and Appreciation," 31.

110 Ben Zvi, "Conversation and Appreciation," 35-6. 
In his answer, Knoppers agrees to a large extent with Ehud ben Zvi, saying,

Chronicles is much more than an exegesis, paraphrase, and elaboration of earlier writings. I think that Ben Zvi and I are in essential agreement on this larger issue so I do not want to belabour this point any further. ${ }^{111}$

One aspect of the problem is perhaps the question of the existence and use of written texts in post-exilic period. Scholars already noticed differences between the Masoretic Text of Chronicles and that of Samuel-Kings. We may ask, therefore, which text was used by the authors of Chronicles. More importantly, as some studies in recent years have firmly established, scribes and copyists did often work from memory rather than exclusively from written sources. People did not work with word-processing programs or photocopy-machines, and we must avoid several anachronistic views. ${ }^{112}$ Copying is not photocopying. In a few words, to say it with Werner H. Kelber, concluding a review of seven books on orality in the biblical world: ${ }^{113}$

There is a palpable discrepancy between the dominantly print medium of modern scholarship and the oral-scribal communication world of its subject matter, with the former encroaching upon the latter. The seven books under review challenge us to (re)consider the Bible in its Jewish and Christian provenance, the biblical and the rabbinic tradition in the media context of the ancient Near Eastern and Mediterranean communications history.

111 Gary N. Knoppers, “Of Rewritten Bibles, Archaeology, Peace, Kings, and Chronicles,” in Melody D. Knowles (ed.), "New Studies,” 69-93, here 75.

112 For a recent publication on the topic orality-literacy, see Brian B. Schmidt (ed.), Contextualizing Israel's Sacred Writings: Ancient Literacy, Orality, and Literary Production, Ancient Israel and Its Literature 22 (Atlanta, GA: Society of Biblical Literature, 2015). Some earlier and important works are William A. Graham, Beyond the Written Word: Oral Aspects of Scripture in the History of Religion (Cambridge: University Press, 1987); Susan Niditch, Oral World and Written Word: Ancient Israelite Literature, Library of Ancient Israel (Louisville: Westminster John Knox, 1996); William M. Schniedewind, How the Bible Became a Book: The Textualization of Ancient Israel (Cambridge: University Press, 2004); David M. Carr, Writing on the Tablet of the Heart: Origins of Scripture and Literature (Oxford: Oxford University Press, 2005); Martin S. Jaffee, Torah in the Mouth: Writing and Oral Tradition in Palestinian Judaism, 200 BCE-400 CE (Oxford: Oxford University Press, 2001); Annette Weissenrieder and Robert B. Coote (eds.), The Interface of Orality and Writing: Speaking, Seeing, Writing in the Shaping of New Genres, WUNT 260 (Tübingen: Mohr Siebeck, 2010). For the history of research, the major works are Eduard Nielsen, Oral Tradition, Studies in Biblical Theology 11 (London: SCM Press, 1954); Werner H. Kelber, "Orality and Biblical Studies: A Review Essay,” RBL 12 (2007): http://www.bookreviews.org/pdf/2107_6748.pdf; Robert D. Miller II, Oral Tradition in Ancient Israel, Biblical Performance Criticism Series 4 (Eugene, OR: Cascade, 2011). 113 Werner H. Kelber, “Orality and Biblical Studies: A Review Essay,” RBL 12 (2007): http://www. bookreviews.org 
This conclusion may have some consequences in several fields, for instance when speaking of "Rewritten Bible" or "innerbiblical exegesis". To put it with Louis C. Jonker, ${ }^{114}$

When one takes the simultaneity of oral and literate cultures in postexilic Israel seriously, it follows that the Chronicler's engagement with the Pentateuch most probably was not primarily with written documents, but rather with fluid memories of those written documents, which nevertheless had authority as transmitted traditions of the past.

\subsection{Additions and Omissions in Chronicles - Juha Pakkala}

The forty pages dedicated to Chronicles in a recent monograph by Juha Pakkala are worth mentioning for their methodological and systematic approach. ${ }^{115}$ The subtitle of the book exposes its program, Omissions in the Tansmission of the Hebrew Bible. Actually, the book's purpose is wider since it discusses several ways of copying, rewriting and transmitting biblical texts. At the outset of the section dedicated to Chronicles, Juha Pakkala discusses previous attempts to define the literary nature of Chronicles. He shows some dissatisfaction with proposals such as "interpretation" ("Auslegung"), ${ }^{116}$ Midrash $^{117}$ or rewritten Bible ${ }^{118}$ because the terminology is too vague. He prefers the theory of replacement, in the sense that Chronicles intends to replace an earlier presentation of Israel's past with a new and more satisfactory one: "[...] the Chronicler wanted to provide a theologically more correct account of Israel's past and thereby replace at least 1-2 Kings as the current and most authoritative account." The Chronicler does more than interpret or supplement his sources. ${ }^{119}$

114 Jonker, "From Paraleipomenon to Early Reader," 225.

115 Juha Pakkala, God's Word Omitted: Omissions in the Transmission of the Hebrew Bible, FRLANT 251 (Göttingen: Vandenhoeck \& Ruprecht, 2013), especially chapter VIII: “Chronicles as a Witness to the Editorial Process," 253-94.

116 Thomas Willi, Die Chronik als Auslegung (see note 63). See Pakkala, God's Words Omitted, $255-5$.

117 Isaac Kalimi, An Ancient Israelite Historian: Studies in the Chronicler, His Time, Place and Writing, SSN 46 (Leiden - Boston, MA: Brill, 2005), 22, observes the presence of midrashic elements in Chronicles, but refuses to call this book a Midrash. See Pakkala, God's Words Omitted, 256, note 10. See also the authors quoted in note 11, Pancratius C. Beentjes, Simon De Vries, and Stephen McKenzie.

118 Pakkala, God's Words Omitted, 256, note 11. But, unfortunately, Pakkala does not seem to know Gary N. Knoppers' commentary on Chronicles.

119 Pakkala, God's Words Omitted, 257. 
The Chronicler's method in rewriting 1-2 Kings is variegated. He can reproduce very faithfully his sources, he can omit certain, often short, parts of the text, or introduce new elements and rework entire sections to adapt them to his theology and world-view: "The Chronicler's position towards the source is somewhere between what is assumed of a classical redactor who made mainly expansions and an author of a new literary work." ${ }^{120}$ For this reason, "A clear-cut division between the redactors and the authors of a new composition is artificial and hazardous." "121 The cases studied by Juha Pakkala ${ }^{122}$ show that the Chronicler did not proceed exactly as the redactors of more ancient parts of the Hebrew Bible: "[...] the principle of preservation seems to have been repeatedly challenged in Chronicles, while the text-critical evidence of the Pentateuch, 1-2 Samuel, and 1-2 Kings shows only isolated instances of such cases and they are more limited in the number of words that are omitted." 123

Pakkala's conclusion draws our attention on some dangers in applying too quickly the Chronicles' model to other parts of the Hebrew Bible: ${ }^{124}$

It should be stressed that Chronicles cannot be used slavishly as a model in the sense that each fundamental change in the society would necessarily cause radical changes in all the texts. It provides an example that fundamental changes must be considered a possibility in the transmission of the Hebrew scriptures, especially in those situations where the fundaments of the society were shaken. Chronicles should thus be included in the construction of a model for the transmission of the Hebrew scriptures and should certainly not be neglected as irrelevant.

\subsection{Importance of the cult, of the monarchy and of Moses' Law}

For several scholars, we find in Chronicles a double attempt of justifying a postexilic form of cult and religion. ${ }^{125}$ First, the organization of the cult goes back to the origin of Israel's united monarchy, to David even more than to Solomon, the latter

120 Pakkala, God's Word Omitted, 260.

121 Pakkala, God's Word Omitted, 289.

1221 Kgs 22:51 and 2 Kgs 8:16-24 // 2 Chr 21:1-20; 2 Kgs 11:1-18 // 2 Chr 22:11-23:18; 2 Kgs 12 // 2 Chr 24.

123 Pakkala, God's Words Omitted, 289.

124 Pakkala, God's Words Omitted, 294.

125 Cf. the seminal article by Simon J. De Vries, "Moses and David as Cult Founders in Chronicles," JBL 107 (1988): 619-39. See also Benjamin D. Giffone, “According to Which 'Law of Moses'? Cult Centralization in Samuel, Kings, and Chronicles," VT 67 (2017): 432-47. 
carrying out David's project. Second, David himself did not invent the organization of the cult. He found its blueprint in Moses' Torah, and followed exactly the prescriptions as they are written in this Torah. This supposes that, for Chronicles, the monarchy is subordinated to Moses' law and that there is already some form of written Pentateuch at the writer's disposal. This opens the questions of the relationship between Chronicles and the cultic, religious, texts in the Pentateuch. Does the Chronicler refer to existing texts when describing the temple's construction and the temple's service? Or, were some sections of the Pentateuch composed to legitimate the postexilic religion in the Second Temple period? Or, do we have to deal with a simultaneous process of using, reinterpreting and completing cultic traditions and/or texts in the Pentateuch when Chronicles was composed? The palpable differences between Exodus 37-40 in the Masoretic Text and in the Old Greek (and Old Latin) could be explained in this context.

\section{Conclusion}

Let me summarize this short history of research in three main points, knowing that much more could be said.

(1) “The older, the better". Chronicles is a witness of an exegetical activity of reinterpreting the past in the Second Temple period, when the Pentateuch slowly became authoritative. ${ }^{126}$ Chronicles refers to several legal traditions as foundation and the legitimation of the cult and religious institutions it describes, subordinating both the monarchy and the cult itself to Moses' Torah. This means that, in this time, Israel looks towards the past to justify and shape its present. "The older is better," to put it with Luke's Gospel (5:39). But one cannot but notice the major importance of David in this re-reading or rewriting of the origins of the Jerusalem cult: "Even though Moses and the Mosaic tradition would continue in honor, it is David who ordained the Levites to their office who brought the worship of Yahweh to its highest perfection and its true fulfillment," according to Simon J. De Vries. ${ }^{127}$

(2) Text criticism and literary criticism are twins. We noticed that the borderline between text criticism and literary criticism is difficult to trace with precision. This was already noticed by Wellhausen in his work on the Books of Samuel. ${ }^{128}$ It

126 On this very point, see now Lars Maskow, Tora in der Chronik. Studien zur Rezeption des Pentateuchs in den Chronikbüchern, FRLANT 274 (Göttingen: Vandenhoeck \& Ruprecht, 2019).

127 De Vries, "Moses and David,” 639.

128 Julius Wellhausen, Der Text der Bücher Samuelis (Göttingen: Vandenhoeck \& Ruprecht, 1871), xi: “[...] es ist schwierig, die Grenze zu finden, wo die Literarkritik aufhört und die Textkri- 
was repeated by Dominique Barthélemy more recently. This means that we probably have to revise some of our presuppositions when trying to identify sources, redactions, additions and omissions in biblical texts. The importance of old versions, such as the LXX and the Old Latin is growing in many exegetical circles.

(3) Copying is not photocopying. Again, recent discoveries, as for instance the Elephantine papyri and the Dead Sea Scrolls, oblige us to revise traditional opinions about the dividing line between orality and literacy. Some problems in the Pentateuch as in Chronicles could find more satisfactory explanations if we take into account the importance of collective memory and oral transmission in ancient times. What is called intertextuality is perhaps to be revised too. A text does not refer necessarily to another text, but perhaps more simply to a collective memory and shared oral traditions.

All in all, we may say that we have more questions than answers and that there is still a lot to be done. Nonetheless, our Cinderella may have met her Fairy Godmother and Sleeping Beauty may also hear from afar the sound of a galloping horse and the voice of her Prince Charming.

tik beginnt." Dominique Barthélemy, "Critique textuelle et critique littéraire,” in Dominique Barthélemy, Découvrir l'Écriture, LD hors série (Paris: Le Cerf, 2000), 141-5; Dominique Barthélemy, "L'enchevêtrement de l'histoire textuelle et l'histoire littéraire dans les relations entre la Septante et le Texte Massorétique,” in Barthélemy, Découvrir l'Écriture, 161-83; Emanuel Tov, Textual Criticism of the Hebrew Bible (Minneapolis, MN: Fortress Press, ${ }^{32012), ~ 313-49 . ~}$ 